\title{
In Vitro Antibacterial, Antioxidant and Mechanism of Antifungal Activities of Selected Indian Traditional Plants against Human Oral Microbes
}

\author{
LAVANYA JAYARAMAN, PERIYAR SELVAM SELLAMUTHU1*, DIVYA PRIYA SIVA, RESHMA SHRII ARAVINDAN, \\ V. VELLAICHAMY AND PRISCILLA MERCY ANITHA \\ Department of Biotechnology, ${ }^{1}$ Department of Food Process Engineering, Postharvest Research Lab, School of \\ Bioengineering, SRM Institute of Science and Technology, Potheri, Kattankulathur, Chengalpattu, Tamil Nadu 603203, India
}

\section{Jayaraman et al.: Antimicrobial Activity of Traditional Plants against Oral Pathogens}

\begin{abstract}
Morus alba, Asparagus racemosus and Murraya koenigii are commonly used in Indian traditional medicines for the various ailments. The plant extracts were analysed for antibacterial, antifungal and antioxidant activities and their mechanism of action towards human oral fungal pathogens. In the present study, methanol extracts were obtained using a soxhlet apparatus and microbes were obtained from microbial type culture collection and gene bank, Pune. The total phenol and flavonoid were found to be high in Murraya koenigii (2.77 mg gallic acid equivalents/g) and Morus alba (160 $\mu \mathrm{g}$ Quercetin equivalent/mg) respectively. The maximum radical scavenging activity was shown by Murraya koenigii in 2,2-diphenylpicrylhydrazyl (71 \%) and 2,2'-azino-bis(3-ethylbenzothiazoline-6-sulfonic acid (82.57 \%) methods. The maximum antibacterial and antifungal activities were observed in Asparagus racemosus towards Lactobacillus acidophilus $(23 \mathrm{~mm})$ and Candida krusei $(10 \mathrm{~mm})$ respectively. The minimum inhibitory concentration was also determined. The target of antifungal activity of Asparagus racemosus towards Candida krusei was not cell wall whereas targets the cell membrane which is confirmed by sorbitol assay, transmission electron microscopy and flow cytometry. This research can be used as a base to find the active components responsible for antibacterial, antifungal and antioxidant activities.
\end{abstract}

Key words: Asparagus racemosus, electron microscope, flow cytometry, Morus alba, Murraya koenigii

Federation Dentaire Internationale (FDI) World Dental Federation stated oral health as multifaceted problem which involves the ability to talk, smile, taste, chew and swallow without any pain, discomfort and disease of the craniofacial complex ${ }^{[1]}$. There has been no improvement in oral health over the past 25 y. Since 1990 , the burden of untreated oral diseases has increased dramatically worldwide because of population growth and aging ${ }^{[2]}$. Dental plaque is the most commonly occurring microbial disease in humans. Dental plaque is considered as a polymicrobial biofilm integrated into an extracellular matrix ${ }^{[3]}$.

Chlorhexidine is an international drug used to treat oral plaques at $0.2 \%$ concentration. However, it has been reported for the adverse side effects such as staining of teeth, dorsum of tongue, alteration of taste and super gingival calculus formation ${ }^{[4]}$. Reducing costs and side effects compared to conventional medicines has led to the use of medicinal plants in the form of mouth rinses

*Address for correspondence E-mail: periyar.india@gmail.com to treat oral diseases considered as promising position on health care over past few years ${ }^{[5]}$. A large number of herbal extracts have been shown to inhibit the oral pathogens and the formation of dental biofilms by minimizing adhering microbial pathogens on the surface of the tooth which is a primary event in development of tooth decay and dental plaque ${ }^{[6-8]}$.

Morus alba (M. alba) is an Indian tradition plant whose parts such as leaves, stems, roots and fruits are used in traditional medicine. The leaves consist of compounds like rutin and quercetin. These natural bioactive compounds have proven biological activities to exhibit excellent pharmacological effects

This is an open access article distributed under the terms of the Creative Commons Attribution-NonCommercial-ShareAlike 3.0 License, which allows others to remix, tweak, and build upon the work non-commercially, as long as the author is credited and the new creations are licensed under the identical terms

Accepted 13 October 2021 Revised 03 August 2021 Received 25 February 2020 Indian J Pharm Sci 2021;83(5):1024-1032 
against numerous diseases. These include diuretic, antioxidant, hypotensive, hypoglycemic, antidiabetic, anticholesterol and antimicrobial properties ${ }^{[9,10]}$. In recent times, most of the research is focused on evaluating the antimicrobial activities of various parts of the plant, many research also focuses on utilization of these medicinal plants in treatment of variety of ailments ${ }^{[1-13]}$. There are very few literatures based on extract of M. alba against oral microorganisms.

Asparagus racemosus (A. racemosus), is from the Liliaceae family and its common name is Shatavari. This plant is considered to be an important monocot medicinal plant found in tropical and subtropical countries like India ${ }^{[14]}$. The roots of this plant is said to be tonic, galactgogue and diuretic. The plant also contains antiseptic and anthelmintic properties ${ }^{[15]}$. Murraya koenigii (M. koenigii) is one of the herbal plants, originates in India typically called curry leaves or karipatta. Due to the presence of numerous phytochemicals, curry leaves exhibit properties like antioxidant, antimicrobial, anticancerous, antidiabetic, antiinflammatory etc., ${ }^{[16]}$ It was found that extracts of M. koenigii inhibit certain dental caries and periodontal pathogens ${ }^{[17]}$.

Medicinal plants are more suitable alternate drug as well as low cost with no side effects when compared to synthetic medicine. The herbal based oral care products are helped to prevent the toxicity and tooth staining. Hence it is necessary to identify the herbal medicine to cure or reduce the symptoms of oral infections. This study is attentive to identify the traditional remedy for oral microbial infections. Therefore our research is focused with the objectives of in vitro antimicrobial activities of $M$. alba, A. racemosus and M. koenigii and antifungal mechanism of action towards human oral pathogens.

\section{MATERIALS AND METHODS}

\section{Collection of plant materials:}

The medicinal plants ( $M$. alba, A. racemosus and $M$. koenigii) were collected from various parts of Tamilnadu, India. The plant identification was authenticated by plant taxonomist Dr. M. Kumar from Madras Christian College, Chennai, Tamil Nadu, India. A voucher specimen were prepared and deposited in Postharvest Research Laboratory, SRM Institute of Science and Technology, Kattankulathur, Tamilnadu, India with voucher No: PRLH10, PRLH11 and PRLH12 respectively.

\section{Preparation of plant extract:}

The collected plant materials were shade dried and ground to a coarse powder. $20 \mathrm{~g}$ of powdered material was weighed and extracted with methanol in a soxhlet apparatus. Extracts were concentrated by using rotary evaporator (IKA, RV 10 digital V) and used for further studies.

\section{Qualitative analysis of phytochemicals:}

The presence of various phytochemicals such as steroids, saponins, terpenoids, glycosides, tannins and flavanoids were preliminary screened by the standard methods $^{[18-21]}$.

\section{Total phenol determination:}

Total phenol was quantitatively determined by FolinCiocalteau colorimetric method. $200 \mu 1$ of plant extract was taken in a screw tube and $1 \mathrm{ml}$ of Folin-Ciocalteau reagent (1:1 with water) and $1 \mathrm{ml}$ of sodium carbonate $(7.5 \%)$ were added. The contents were thoroughly mixed using vortex. After $2 \mathrm{~h}$ of incubation, the mixture was tested for phenolic content at $726 \mathrm{~nm}$ in UltravioletVisible (UV-Vis) spectrophotometer (Beckman, USA) and expressed in Gallic Acid Equivalents (GAE) in $\mathrm{mg} / \mathrm{g}$ of plant extract ${ }^{[22]}$.

\section{Total flavonoid determination:}

Total flavonoid content was determined using aluminium chloride colorimetric method. Plant extract was dissolved in methanol in the ratio 1:10 (w/v) and then mixed with a mixture containing $0.1 \mathrm{ml}$ of $10 \%$ aluminium chloride hexahydrate, $0.1 \mathrm{ml}$ of $1 \mathrm{M}$ potassium acetate and $2.8 \mathrm{ml}$ of deionized water. After 40 min of incubation, the mixtures were analysis at $415 \mathrm{~nm}$ in UV-Vis spectrophotometer (Beckman, USA) using quercetin was used as the standard. The result was expressed in $\mu \mathrm{g}$ Quercetin Equivalents (QE) per $\mathrm{mg}$ of dry extracts ${ }^{[22]}$.

\section{ANTIOXIDANT ACTIVITY}

\section{2,2-diphenylpicrylhydrazyl (DPPH) radical scavenging activity:}

Antioxidant activity of the plant extracts was determined using DPPH radical scavenging activity. The plant extracts were diluted in the concentrations ranging from $100-500 \mu \mathrm{g} / \mathrm{ml}$. The $50 \mu \mathrm{l}$ of sample was taken in a 96 well micro titer plate (triplicates). Afterwards $100 \mu \mathrm{l}$ of $0.1 \mathrm{~mm}$ DPPH was added and incubated for $30 \mathrm{~min}$. The absorbance was measured at $515 \mathrm{~nm}$. 
The $50 \mu 1$ of methanol in $100 \mu 1$ of DPPH was used as control and $100 \mu 1$ of $95 \%$ methanol was used as the blank. Different concentrations of ascorbic acid $(100-500 \mu \mathrm{g} / \mathrm{ml})$ were used as standard. Free radical scavenging activity is inversely proportional to the absorbance measured ${ }^{[23]}$.

The ability to scavenge the DPPH radical was calculated using the following equation:

DPPH Scavenged $(\%)=[\mathrm{OD}$ control-OD sample/OD control] $\times 100$

\section{2,2'-azino-bis(3-ethylbenzothiazoline-6-sulfonic acid (ABTS) free radical scavenging activity:}

The free radical scavenging capacity of plant extract was determined by ABTS radical cation decolorization assay using $0.7 \mathrm{~mm}$ ABTS. ABTS stock solution in the presence of $2.45 \mathrm{~mm}$ potassium persulphate produces ABTS+ (Cation). This was kept in a dark room for 12-16 $\mathrm{h}$ before use. The ABTS+ was diluted in $70 \%$ ethanol and adjusted to an absorbance of $0.700( \pm 0.02)$ at $734 \mathrm{~nm}$. This reading was taken as blank $\left(\mathrm{A}_{0}\right)$. The $20 \mu 1$ of test sample and $2 \mathrm{ml}$ of ABTS+ solution were added and the absorbance was recorded exactly after 6 min from initial mixing $\left(A_{t}\right)$. Concordant absorbance values were taken ${ }^{[24]}$.

The percentage inhibition (PI) of absorbance at $734 \mathrm{~nm}$ was calculated using the formula:

$\mathrm{PI}=\left[\mathrm{AC}_{(0)}-\mathrm{AA}_{(\mathrm{t})} / \mathrm{AC}_{(0)}\right] \times 100$

Where, $\mathrm{AC}_{(0)}$ is the absorbance of the control at $\mathrm{t}=0 \mathrm{~min}$; $\mathrm{AA}_{(\mathrm{t})}$ is the absorbance of the antioxidant at $\mathrm{t}=6 \mathrm{~min}$

\section{ANTIMICROBIAL ACTIVITY}

\section{Microbial strains:}

Oral pathogenic bacteria such as Staphylococcus aureus (S. aureus) (Microbial Type Culture Collection \& Gene Bank (MTCC) 7443), S. mutans (MTCC 497), S. mitis (MTCC 2695), S. oralis (MTCC 2696), Lactobacillus acidophilus (L. acidophilus) (MTCC 10307) and Pseudomonas aeruginosa (P. aeruginosa) (MTCC 7453 ) and fungal species such as Candida parapsilosis (C. parapsilosis) (MTCC 6510), C. krusei (MTCC 9215) and C. tropicalis (MTCC 184) were obtained from MTCC, Chandigarh, India.

\section{Disc diffusion method:}

The antibacterial and antifungal activity of plant extracts were determined by disc diffusion method. The strains were cultured in Muller-Hinton (MH) broth to logarithmic phase and were adjusted to $0.5 \mathrm{McF}$ arland's using the same broth. The test strains were spread on the Muller-Hinton agar plates at $37^{\circ}$ for $24-48 \mathrm{~h}$. A sterile disc of $100 \mu \mathrm{g} / \mathrm{ml}$ and $250 \mu \mathrm{g} / \mathrm{ml}$ concentration was used to test the antibacterial and antifungal activities respectively. Plant extracts dissolved in Dimethyl Sulphoxide (DMSO) was added to sterile discs and impregnated onto agar plate with specific pathogenic strain. The $30 \mu \mathrm{g} / \mathrm{ml}$ of chloramphenicol, $0.5 \mathrm{mg} / \mathrm{ml}$ of fluconazole and $100 \%$ DMSO were used as the positive and negative control respectively. The zone of inhibition was checked after $24-48 \mathrm{~h}$ of incubation ${ }^{[25,26]}$.

\section{Determination of Minimum Inhibitory Concentration (MIC):}

The MIC of extracts was determined using serial dilution method. The extracts were diluted in a twofold. $2 \mathrm{ml}$ of $\mathrm{MH}$ broth along with plant extract was taken in tube 1. This served as the stock for the further dilution. $1 \mathrm{ml}$ of this stock was added to the $2^{\text {nd }}$ tube and $1 \mathrm{ml}$ of MH broth was added to it. Tubes 2-10 were diluted using the same procedure. $1 \mathrm{ml}$ of inoculums (test strains cultured in $\mathrm{MH}$ broth) was added to the tubes and was incubated at $37^{\circ}$ for $24-48 \mathrm{~h}$. The $\mathrm{MH}$ broth was used as the negative control. All the tubes were made in triplicates ${ }^{[27]}$.

\section{Sorbitol binding assay:}

The effect of plant extracts on fungal cell wall was determined using sorbitol assay by the method of Frost et al. The 96 well plates containing test compounds with and without $0.1 \mathrm{M}$ sorbitol in adjacent rows were prepared. The $100 \mu$ l of fungal suspension was added to each well. The readings were taken after $2^{\text {nd }}$ and $6^{\text {th }} \mathrm{d}$ of incubation and MIC was calculated ${ }^{[28]}$.

\section{Scanning electron microscopy (SEM):}

Samples for SEM analysis were prepared according to Figueras and Guarro, method with slight modifications. The $100 \mu$ l of cells was inoculated in with Sabouraud's dextrose broth at the MIC concentration of plant extracts and was incubated at $37^{\circ}$ for $48 \mathrm{~h}$ at $120 \mathrm{rpm}$. It was then centrifuged to obtain cell pellets. The pellets along with untreated controls were fixed with $3 \%$ glutaraldehyde in $0.05 \mathrm{M}$ phosphate buffer ( $\mathrm{pH}$ 6.8) at $4^{\circ}$ for $48 \mathrm{~h}$. It was then dehydrated for 20 min using $30 \%, 50 \%, 70 \%, 95 \%$ ethanol and absolute ethanol for $45 \mathrm{~min}$. The samples were dried using liquid carbon dioxide $\left(\mathrm{CO}_{2}\right)$ at critical point and was mounted onto standard $1 / 2$ inch Cambridge SEM tubes and coated with 
Gold-Palladium electroplating (60 s, 1.8 mA, $2.4 \mathrm{kv}$ ) in a Polaron SEM coating system sputter coater. The samples were examined in a LEO 435 VP SEM at $15 \mathrm{kv}$ to study the changes in cell morphology ${ }^{[29]}$.

\section{Transmission Electron Microscopy (TEM):}

Structural changes imparted by test compounds on fungal cell wall were evaluated using TEM. The 100 $\mu 1$ of cell suspension ( $0.5 \mathrm{McF}$ arland) was added to $10 \mathrm{ml}$ of Sabouraud's dextrose broth treated with MIC concentration of plant extracts and incubated at $37^{\circ}$ for $48 \mathrm{~h}$ at $120 \mathrm{rpm}$. Untreated samples were used as a control. The obtained cell pellets were fixed using $2.5 \%$ glutaraldehyde in $0.1 \mathrm{M}$ cacodylate buffer $(\mathrm{pH}$ 7.2) for $24 \mathrm{~h}$ at room temperature. This was post fixed using $1 \%$ osmium tetroxide in cacodylate buffer. Samples were dehydrated in acetone and embedded in epon. Ultra-thin sections were stained with $12.5 \%$ alcoholic uranyl acetate and viewed under Morgagni 268D transmission electron microscope at $80 \mathrm{kv}$. The difference in the ultra-structure of treated and untreated samples were analysed ${ }^{[29]}$.

\section{Propidium iodide influx analysis:}

Propidium iodide influx analysis was done according to Cho et al. method. C. parapsilosis cells $\left(2 \times 10^{6}\right.$ cells $/ \mathrm{ml}$ ) in $\log$ phase were inoculated in yeast extract peptone dextrose medium. The plant extracts were added and incubated for $2 \mathrm{~h}, 28^{\circ}$ at $140 \mathrm{rpm}$. The cells were harvested, resuspended in Phosphate Buffered Saline (PBS) and treated with propidium iodide ( $9 \mu \mathrm{m}$, final concentration) for $5 \mathrm{~min}$. Flow cytometry was performed via Fluorescence-Activated Cell Sorting (FACS) Caliber flow cytometry ${ }^{[30]}$.

\section{Flow cytometric analysis:}

Morphological changes imparted by plant extracts onto Candida cells were determined by flow cytometry by illuminating the cells at $480 \mathrm{~nm}$ using an argon ionic laser, Forward Light Scatter (FSC) and Side Scatter (SSC).

\section{Statistical analysis:}

Results were expressed as mean \pm Standard Deviation (SD) for triplicates. All the data were statistically evaluated with Statistical Package for the Social Sciences (SPSS)/19.0 software.

\section{RESULTS AND DISCUSSION}

The analysis of various phytochemicals such as steroids, saponins, terpenoids, glycosides, tannins, phenols and flavonoids were carried out in $M$. alba, A. racemosus and $M$. koenigii. The result showed the presence of all phytochemicals except steroids in A. racemosus and terpenoids in $M$. koenigii (Table 1).

The phenol and flavonoid content was tested using Folinphenol reagent and aluminium chloride respectively. The result of total phenol and flavonoid were expressed in GAE/g and QE/mg respectively (Table 2 ).

Among the sample tested $M$. koenigii showed significantly $(\mathrm{p}<0.05)$ higher phenolic content followed by $M$. alba. The M. alba showed higher flavonoid content followed by $M$. koenigii. The phenol and the flavonoid contents of $M$. koenigii leaves were found to be $2.77 \mathrm{mg} / \mathrm{g}$ and $66 \mu \mathrm{g} / \mathrm{mg}$ respectively. The above result correlates with Thangavel et al. and Pratima et al. ${ }^{[31,32]}$. Phenolic content of the plant is directly proportional to the antioxidant activity ${ }^{[33]}$ as it absorbs the free radicals by decomposing peroxide ${ }^{[34,35]}$. Our results confirmed the above said statement.

The presence of phytochemicals like phenols and flavonoids makes this plant a potent antioxidant ${ }^{[36]}$ and the methanolic extract of $M$. koenigii can scavenge cationic and neutral free radicals due to the presence of these phytochemicals ${ }^{[37]}$.

Our result also confirmed that $M$. koenigii possess high phenol content also showed high radical scavenging activity $(71 \%)$. The $M$. alba and $A$. racemosus showed $49 \%$ and $23 \%$ of radical scavenging activity respectively. Zhishen et al. reported that mulberry leaves showed the superoxide ion scavenging activity by $46.5 \%$ at $5 \mu \mathrm{g} / \mathrm{ml}$ concentration ${ }^{[38]}$. M. koenigii leaves extract showed $96 \%$ radical scavenging activity at $0.1 \mathrm{mg} / \mathrm{ml}^{[39]}$. Benzene extract of $M$. koenigii showed the highest activity of $88.3 \%{ }^{[40]}$.

Oxidation of ABTS with potassium per sulphate generates ABTS free radicals and it is based on the antioxidant capacity of the unknown compounds to reduce free radical. The scavenging activity of $M$. koenigii was significantly higher $(82.57 \%)$ than the other two plants extracts (M. alba $(60.4 \%)$ and A. racemosus $(26.57 \%)$ ). The standard vitamin E showed $99.6 \%$ scavenging activity. M. koenigii showed $100 \%$ radical scavenging activity at $10 \mu \mathrm{g} /$ $\mathrm{ml}^{[41]}$ and the antioxidant activity of three different varieties of M. koenigii were $12-75 \%$ at $40 \mu \mathrm{g} / \mathrm{ml}$ and the high antioxidant activity is due to the presence of high phenolic content in $M$. koenigii ${ }^{[42]}$.

The extracts of $M$. alba, A. racemosus and M. koenigii 
$(100 \mu \mathrm{g} / \mathrm{ml})$ and chloramphenicol $(30 \mu \mathrm{g} / \mathrm{ml})$ showed significant antibacterial activity for most of the bacteria tested except Streptococcus mitis (S. mitis) (S. mitis and $S$. mutans) are the most common bacteria in cariogenicity of human teeth and they possess moderate resistance to antibiotics ${ }^{[43]}$. Our results also confirmed that $S$. mitis are resistant to all extracts tested and $S$. mutans susceptible only to M. koenigii (18 mm) (Table 3 ).

The methanolic extracts of $M$. alba and A. racemosus showed maximum antibacterial activity $(23 \mathrm{~mm})$ against $S$. oralis and $L$. acidophilus respectively (Table 3). These results coincide with Aditya et al. ${ }^{[44]}$ and Chaitali et al. ${ }^{[45]}$. Baskaran et al. ${ }^{[46]}$ concluded antibacterial activity of $M$. koenigii against $S$. aureus $(15 \mathrm{~mm})$ and $P$. aeruginosa $(8 \mathrm{~mm})$. The antibacterial activity of mulberry was due to the presence of high concentration of phenolic acids ${ }^{[47]}$.

The fungal species showed the resistance towards all the extracts tested except $C$. kruse $i$ sensitive to $A$. racemosus

\begin{tabular}{|c|c|c|c|}
\hline Phytochemicals & M. alba & A. racemosus & M. koenigii \\
\hline Steroids & + & - & + \\
\hline Saponins & + & + & + \\
\hline Terpenoids & + & + & - \\
\hline Glycosides & + & + & + \\
\hline Tannins & + & + & + \\
\hline Flavonoids & + & + & + \\
\hline Phenols & + & + & + \\
\hline
\end{tabular}

Note: (+) Present; (-) Absent

TABLE 2: TOTAL PHENOL AND FLAVONOID ESTIMATION OF $M$. alba, $A$. racemosus AND $M$. koenigii

\begin{tabular}{lcc}
\hline $\begin{array}{l}\text { Methanolic } \\
\text { extract }\end{array}$ & $\begin{array}{c}\text { Total phenolic content } \\
(\mathrm{mg} \mathrm{GAE} / \mathrm{g})\end{array}$ & $\begin{array}{c}\text { Flavanoid content } \\
(\mu \mathrm{g} \mathrm{QE} / \mathrm{mg})\end{array}$ \\
\hline M. alba & $1.50 \pm 0.05^{\mathrm{b}}$ & $160 \pm 2.00^{\mathrm{c}}$ \\
A. racemosus & $0.28 \pm 0.01^{\mathrm{a}}$ & $3.5 \pm 0.50^{\mathrm{a}}$ \\
M. koenigii & $2.77 \pm 0.03^{\mathrm{c}}$ & $66 \pm 1.00^{\mathrm{b}}$ \\
\hline
\end{tabular}

Note: Data are represented as mean \pm SD, with experiments carried out in triplicates. Values with various superscripts denote significant difference among different plant extracts $(p<0.05)$
$(10 \pm 0.55 \mathrm{~mm})$ and at $250 \mu \mathrm{g} / \mathrm{ml}$ concentrations (Table 4) and MIC was $62.5 \mathrm{mg} / \mathrm{ml}$. Our results were similar with Uma et al. ${ }^{[48]}, C$. krusei showed sensitivity towards the methanol extract of $A$. racemosus. The MIC for antibacterial activity ranges from $0.5-6.25 \mu \mathrm{g} / \mathrm{ml}$ (Table 5).

The assay was performed to determine the action of plant extracts on fungal cell wall. The MIC (62.5 mg/ml) of A. racemosus towards C. krusei was similar in both presence and absence of sorbitol $(0.8 \mathrm{M})$ clearly indicates the target of inhibition of plant extract towards fungi was not by cell wall synthesis.

Citral, an unsaturated monoterpene aldehyde showed the identical MIC values in both presence and absence of sorbitol ${ }^{[49]}$ showed that the target of antifungal compound is not cell wall ${ }^{[50]}$. Our results also showed the identical MIC values both in presence and absence of sorbitol confirmed the target is not the cell wall.

SEM was performed to determine the morphological changes in C. krusei after treatment with the MIC concentration of $A$. racemosus $(62.5 \mathrm{mg} / \mathrm{ml})$ for $48 \mathrm{~h}$ (fig. 1a, fig. 1b). Untreated cells were regular with intact spherical shape and uniform central density whereas, plant extracts treated cells showed changes in morphology. The cells showed irregular shape with deformed surface and elongated. This indicates the bactericidal activity of $A$. racemosus on losing cell membrane integrity and release of cytoplasmic contents which leads to cell death.

The mechanism of action of antifungal activity was analysed using TEM. The untreated cell of C. krusei showed a regular spherical morphology with clear cytoplasm and smooth surface (fig. 2a) whereas the plant extract treated cell showed an irregular shape and an improper cell membrane. This confirms the damage in the cell membrane which leads to the disruption in the semi permeability transport of molecules across the cell membrane. This is followed by the deterioration and reduced intracellular volume of cytoplasm and cellular constituents, results in structural disorganization and

TABLE 3: ANTIBACTERIAL ACTIVITIES OF M. alba, A. racemosus AND M. koenigii

\begin{tabular}{lcccc}
\hline Microorganism & M. alba & A. racemosus & M. koenigii & Chloramphenicol \\
\hline S. aureus & $19 \pm 2.08$ & $17 \pm 2.08$ & $12 \pm 1.52$ & $24 \pm 0.15$ \\
S. mitis & - & - & - & $15 \pm 0.28$ \\
S. oralis & $23 \pm 2.64$ & $15 \pm 2.51$ & - & $19 \pm 0.8$ \\
S. mutans & - & - & $18 \pm 1.52$ & $22 \pm 0.57$ \\
L. acidophilus & - & $23 \pm 3.60$ & - & $9 \pm 1.75$ \\
P. aeruginosa & $20 \pm 2.08$ & - & $10 \pm 1.52$ & $20 \pm 0.52$ \\
\hline
\end{tabular}

Note: Values are mean inhibition zone $(\mathrm{mm}) \pm \mathrm{SD}$ of triplicates, plant extracts-100 $\mu \mathrm{g} / \mathrm{ml}$; chloramphenicol-30 $\mu \mathrm{g} / \mathrm{ml} ;(-) \mathrm{no}$ inhibition 
reduced intracellular volume of cytoplasm finally causes cell death (fig. 2b-fig. 2g). This result coincides with our previous study ${ }^{[51]}$. The ethanolic extract of whole fruit of pomegranate was tested against C. albicans, C. krusei and C. rugosa. The MIC was observed at the concentration of $125 \mu \mathrm{g} / \mathrm{ml}$. The vacuole formation, irregular hyphae were identified in the C. albicans treated with pomegranate extract by $\mathrm{TEM}^{[52]}$.

Flow cytometry was performed to evaluate the effect of the drug on cell membrane. The increased fluorescence was observed due to the internalization of propidium iodide in cells with severe membrane lesions. The following graph explains the cell membrane damage in $C$. krusei by $A$. racemosus at MIC concentration

TABLE 4: ANTIFUNGAL ACTIVITIES OF M. alba, A. racemosus AND M. koenigii

\begin{tabular}{lccc}
\hline Plant extracts & C. parapsilosis & C. krusei & C. tropicalis \\
\hline M. alba & - & - & - \\
A. racemosus & - & $10 \pm 0.55$ & - \\
M. koenigii & - & - & - \\
Fluconazole & $19 \pm 3.21$ & $24 \pm 1.07$ & $13 \pm 3.5$
\end{tabular}

Note: Values are mean inhibition zone $(\mathrm{mm}) \pm \mathrm{SD}$ of three replicates, plant extracts- $250 \mu \mathrm{g} / \mathrm{ml}$; fluconazole- $0.5 \mathrm{mg} / \mathrm{ml}$, (-) no inhibition

TABLE 5: MIC VALUES OF $M$. alba, A. racemosus AND $M$. koenigii AGAINST ORAL BACTERIA

\begin{tabular}{lccc}
\hline Bacteria & M. alba & A. racemosus & M. koenigii \\
\hline S. aureus & 1.56 & 3.12 & 3.12 \\
S. mitis & - & - & - \\
S. oralis & 1.56 & 6.25 & - \\
S. mutans & - & - & 3.12 \\
L. acidophilus & - & 6.25 & - \\
P. aeruginosa & 3.12 & - & 1.56 \\
\hline
\end{tabular}

(62.5 mg/ml). Morphological changes were observed on scatter gram upon treatment with test agents. The graph clearly mentioned that cell count damage is high in treated sample (orange colour) than untreated (blue). DMSO (green) was used as a negative control (fig. 3). This results were coinciding with our previous study ${ }^{[51]}$. The present study confirms the presence of antibacterial, antifungal and antioxidant activities of the Indian traditional plants. Future detailed investigation on these plants hopefully lead to the development of medical applications.

In this study, the antimicrobial and antioxidant activities of three traditional plants which were used by the traditional practitioners for oral infections were assessed. The phenol content is found to be high in M. koeingii and flavonoids are high in M. alba. The presence of high concentrations of phenols in M. koeingii and flavonoids in M. alba makes these plants a potent antioxidant and antimicrobial respectively. Based on the available literatures, mechanism of phenol is to alter cell membrane potential which disrupts ion transport and cause cell death which was confirmed by TEM. The potent antifungal activity was observed in $A$. racemosus towards $C$. krusei by deteriorating cell membrane which results in the damage of overall morphology.

Future directions based on this research includes the identification of specific phytochemicals responsible for activity, synergistic effect of plant extracts and the possible route of administration of the specific phytochemicals for the proper release of active antimicrobial compound at the target site of infection.

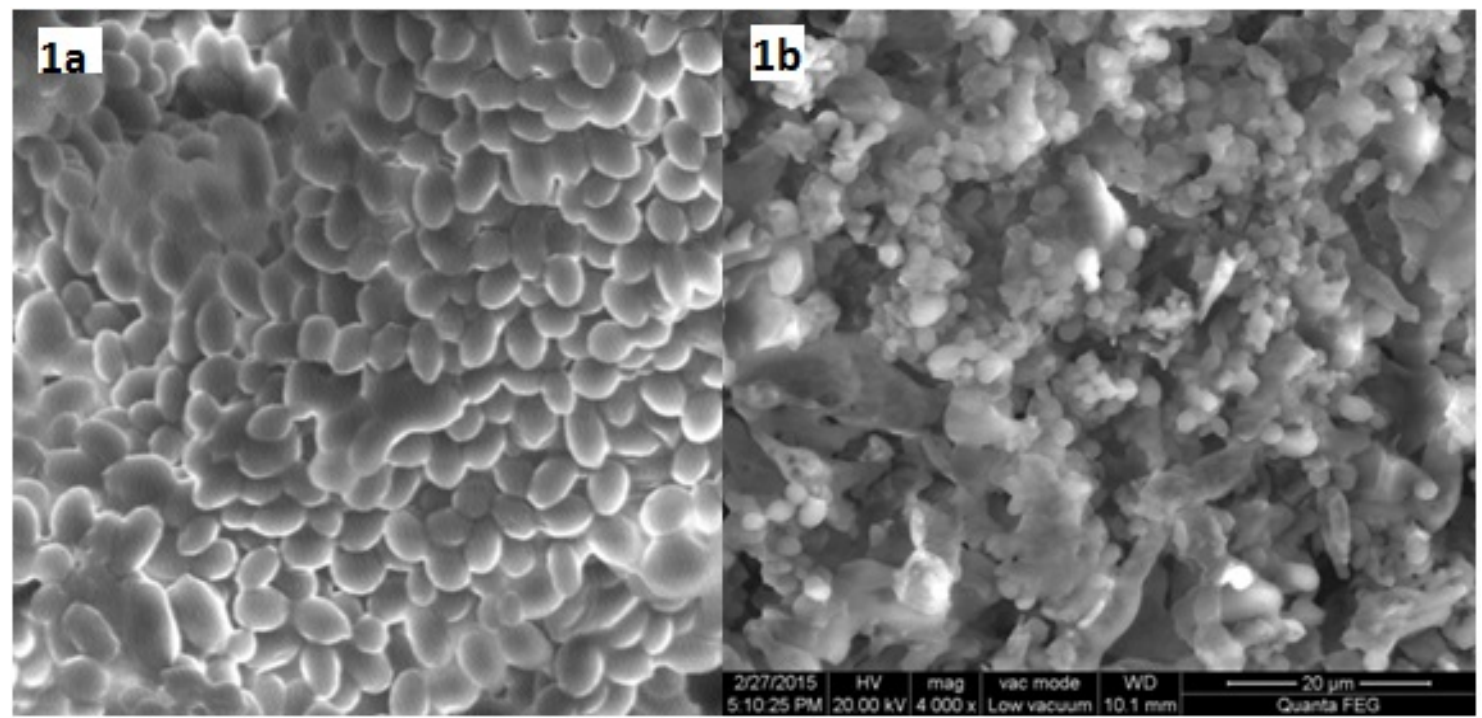

Fig. 1: SEM micrographs of (a) C. kusei untreated cells with uniform morphology; (b) treated cells with deformed and elongated morphology 


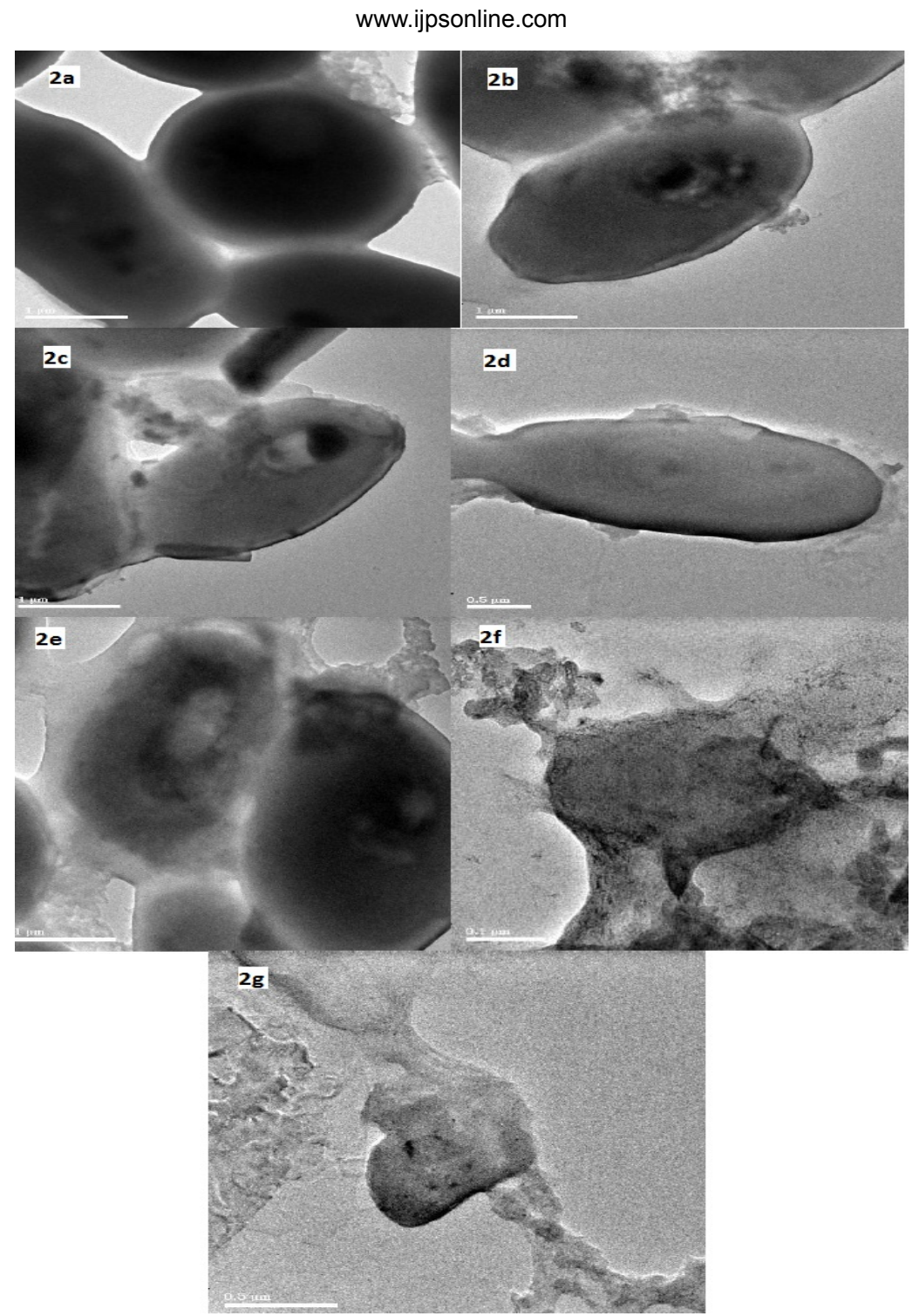

Fig. 2: (a) TEM images of untreated $C$. krusei cells with intact and uniform cell density; (b-g) TEM images of $C$. krusei with $A$. racemosus treated sample with non-uniform cell density, deteriorated cell membrane and reduced intracellular volume of cytoplasm

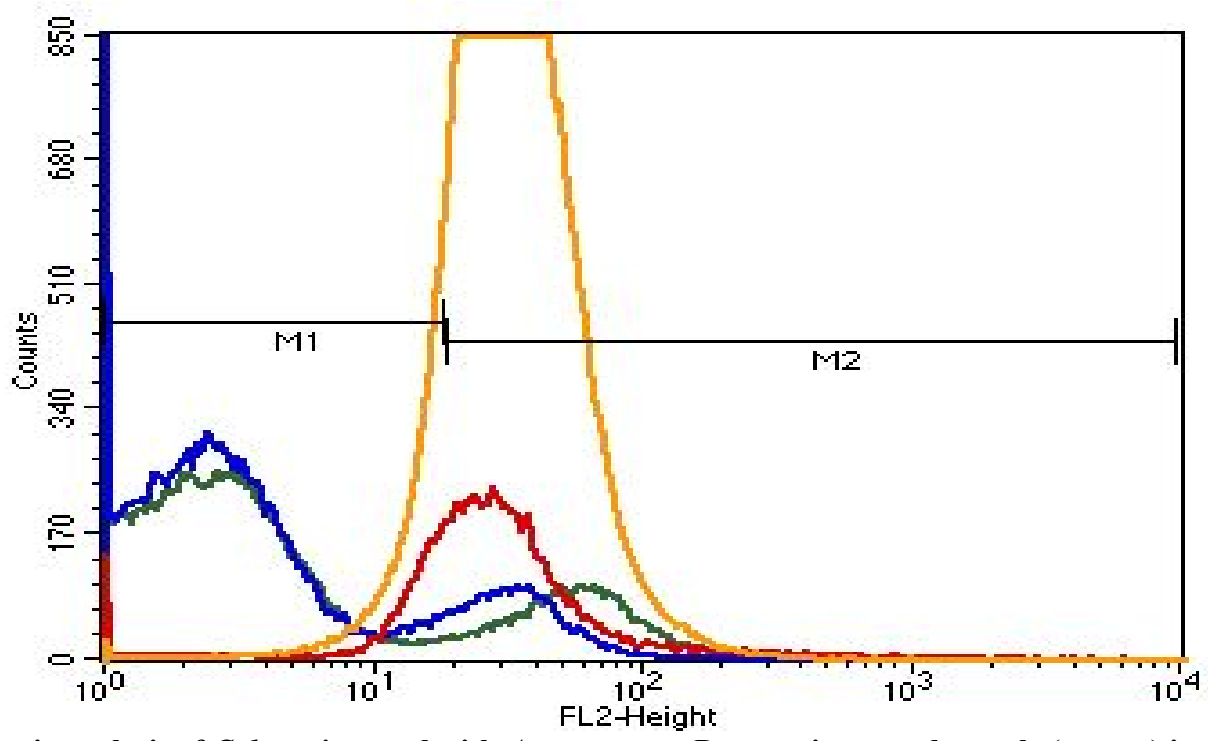

Fig. 3: Flow cytometric analysis of $C$. krusei treated with $A$. racemosus. Damage in treated sample ( $)$ is comparatively higher than untreated sample ( $)$ due to the influx of propidium iodide into cells, antibiotic; ( ) plant extract; ( DMSO; 
Therefore further investigations are required to identify the active compounds of the medicinal plants to develop oral care products for the oral infections.

\section{Conflicts of interest:}

The authors declared no conflicts of interest.

\section{REFERENCES}

1. Glick M, Williams DM, Kleinman DV, Vujicic M, Watt RG, Weyant RJ. A new definition for oral health developed by the FDI World Dental Federation opens the door to a universal definition of oral health. Br Dent J 2016;221(12):792-3.

2. Kassebaum NJ, Smith AG, Bernabé E, Fleming TD, Reynolds AE, Vos T, et al. GBD 2015 Oral Health Collaborators. Global, regional and national prevalence, incidence and disabilityadjusted life years for oral conditions for 195 countries, 19902015: a systematic analysis for the global burden of diseases, injuries and risk factors. J Dent Res 2017;96(4):380-7.

3. Valm AM. The structure of dental plaque microbial communities in the transition from health to dental caries and periodontal disease. J Mol Biol 2019;431(16):2957-69.

4. Jain I, Jain P, Bisht D, Sharma A, Srivastava B, Gupta N. Use of traditional Indian plants in the inhibition of caries-causing bacteria-Streptococcus mutans. Braz Dent J 2015;26(2):110-5.

5. Santi SS, Casarin M, Grellmann AP, Chambrone L, Zanatta FB. Effect of herbal mouth rinses on dental plaque formation and gingival inflammation: A systematic review. Oral Dis 2021;27(2):127-41.

6. Arumugam B, Subramaniam A, Alagaraj P. A Review on Impact of Medicinal Plants on the Treatment of Oral and Dental Diseases. Cardiovasc Hematol Agents Med Chem 2020;18(2):79-93.

7. Choi HA, Cheong DE, Lim HD, Kim WH, Ham MH, Oh $\mathrm{MH}$, et al. Antimicrobial and anti-biofilm activities of the methanol extracts of medicinal plants against dental pathogens Streptococcus mutans and Candida albicans. J Microbiol Biotechnol 2017;27(7):1242-8.

8. Angaji EBSA, Angaji SM. Antimicrobial effects of four medicinal plants on dental plaque. J Med Plant Res 2009;3(3):132-7.

9. Hussain F, Rana Z, Shafique H, Malik A, Hussain Z. Phytopharmacological potential of different species of Morus alba and their bioactive phytochemicals: A review. Asian Pac J Trop Biomed 2017;7(10):950-6.

10. Wen P, Hu T, Linhardt RJ, Liao ST, Wu H, Zou YX. Mulberry: A review of bioactive compounds and advanced processing technology. Trends Food Sci Technol 2019;83:138-58.

11. Arya KR, Prakash V. Ethnomedicinal study of a remote tribal area of Almora district: A survey report-Part I. In: Maheshwari JE, editor. Ethnobotany and Medicinal Plants of Indian Subcontinent. Jodhpur: Scientific Publishers; 2003. p. 247-52.

12. Kanwar P, Sharma N, Rekha A. Medicinal plants use in traditional healthcare systems prevalent in Western Himalayas. Ind J Tradit Knowl 2006;5(3):300-9.

13. Sharma V, Joshi BD. Bio-diversity of medicinal plants in some selected areas of Almora district. J Environ Biosci 2008;22:3942.

14. Gomase VS, Sherkhane AS. Isolation, structure elucidation and biotransformation studies on secondary metabolites from Asparagus racemosus. Int J Microbiol 2010;2(1):7-9.

15. Sinha N, Biswas M. Effect of extracts from Asparagus racemosus Wild root against pathogenic bacteria. Int J Applied Biol Pharm Technol 2011;2:312-4.

16. Parashar M, Mudgal G, Kaur J. Phytochemical profiling, antimicrobial and antioxidant activities on leaves extract of Murraya koenigii. Plant Cell Biotechnol Mol Biol 2020;21(1516):303-13.

17. Shekar BRC, Nagarajappa R, Suma S, Thakur R. Herbal extracts in oral health care-A review of the current scenario and its future needs. Pharmacogn Rev 2015;9(18):87-92.

18. Harborne JB. Methods of plant analysis. Phytochem Meth. Springer Netherlands. 1984;1-36.

19. Sofowora A. Recent trends in research into African medicinal plants. J Ethnopharmacol 1993;38(2-3):197-208.

20. Evans WC. Trease and Evans' pharmacognosy. Elsevier Health Sciences; 2009.

21. Singleton VL, Rossi JA. Colorimetry of total phenolics with phosphomolybdic-phosphotungstic acid reagents. Am J Enol Vitic 1965;16:144-58.

22. Lin JY, Tang CY. Determination of total phenolic and flavonoid contents in selected fruits and vegetables, as well as their stimulatory effects on mouse splenocyte proliferation. Food Chem 2007;101(1):140-7.

23. Sharma OP, Bhat TK. DPPH antioxidant assay revisited. Food Chem 2009;113(4):1202-5.

24. Re R, Pellegrini N, Proteggente A, Pannala A, Yang M, RiceEvans C. Antioxidant activity applying an improved ABTS radical cation decolorization assay. Free Rad Biol Med 1999;26(9-10):1231-7.

25. Bauer AW, Kirby WM, Sherris JC, Turck M. Antibiotic susceptibility testing by a standardized single disk method. Am J Clin Pathol 1966;45(4):493-6.

26. McFarland J. Standardization of bacterial culture for the disc diffusion assay. J Am Med Assoc 1987;49:1176-8.

27. Baron EJ, Finegold SM, Scotts B. Diagnostic Microbiology. 8th ed. USA: Mosby; 1990.p.176-82.

28. Frost DJ, Brandt, KD, Cugier D, Goldman R. A whole-cell Candida albicans assay for the detection of inhibitors towards fungal cell wall synthesis and assembly. J Antibiot (Tokyo) 1995;48(4):306-10.

29. Figueras MJ, Guarro J. X-ray microanalysis of black piedra. Antonie van Leeuwenhoek 1997;72(4):275-81.

30. Cho J, Choi H, Lee J, Kim MS, Sohn HY, Lee DG. The antifungal activity and membrane-disruptive action of dioscin extracted from Dioscorea nipponica. Biochim Biophys Acta 2013;1828(3):1153-8.

31. Thangavel A, Sahu O, Ponnappan S, Tadele A, Abawa G, Karthikeyan M. Evaluation of preliminary phytochemical constituents and antibacterial activity of edible plants against urinary tract infections causing bacteria in children. J Clin Microbiol Biochem Technol 2017;3(2):24-30.

32. Pratima V, Rekha V. Assessment of phytochemicals and antioxidant activities of Murraya koenigii Linn. Int J Pharm Sci Res 2015;7(5):2163-7.

33. Yingming P, Ying L, Hengshan W, Min L. Antioxidant activities of several Chinese medicine herbs. Food Chem 2004;88(3):347-50.

34. Oktay M, Gulcin I, Kufrevioglu OI. Determination of in vitro antioxidant activity of fennel (Foeniculum vulgare) seed extracts. Food Sci Tech 2003;36:263-71.

35. Proestos C, Lytoudi K, Mavromelanidou OK, Zoumpoulakis P, Sinanoglou VJ. Antioxidant capacity of selected plant extracts and their essential oils. Antioxidants 2013;2:11-22.

36. Rengasamy B, Dhanraj V, Hee J, Palanivel G, Su Kim, Dong- 
Kug C. Medicinal profile, phytochemistry and pharmacological activities of Murraya koenigii and its primary bioactive compounds. Antioxidants 2020;9(2):101.

37. Keerati T, Pisit P, Nakarin S, Jaturong K, Saisamorn L. Phytochemical analysis and evaluation of antioxidant and biological activities of extracts from three Clauseneae plants in Northern Thailand. Plants 2021;10(1):117.

38. Zhishen J, Mengcheng T, Jiaming W. The determination of flavonoids contents in mulberry and their scavenging effect on superoxide radicals. Food Chem 1999;64(4):555-9.

39. Deepak D, Rakesh KP, Singh V. Antioxidant and antibacterial potential of Murraya koenigii against human cariogenic pathogens. Int J Pharm Sci Res 2012;3:3399-406.

40. Maryam Z, Farrukh A, Mabood FH, Iqbal A. Antioxidant capacity and antimutagenic potential of Murraya koenigii. Bio Med Res Int 2013(1):263509.

41. Sasidharan I, Nirmala Menon A. Effects of temperature and solvent on antioxidant properties of curry leaf (Murraya koengii L.). J Food Sci Technol 2011;48(3):366-70.

42. Sivakumar CV, Meera I. Antioxidant and biological activities of three morphotypes of Murraya koengii L. from Uttarakhand. J Food Pro Tech 2013;4:1-7.

43. Venditti M, Baiocchi P, Santini C, Brandimarte C, Serra $\mathrm{P}$, Gentile G, et al. Antimicrobial susceptibilities of Streptococcus species that cause septicemia in neutropenic patients. Antimicrob Agents Chemother 1989;33(4):580-2.

44. Aditya Rao SJ, Ramesh CK, Mahmood R, Prabhakar BT. Antihelminthic and antimicrobial activities in some species of mulberry. Int J Pharm Pharm Sci 2012;4(5):335-8.

45. Chaitali RN, Preeti, Malti. Antimicrobial activity of leaf extract of Morus indica (Mulberry) from Chhattisgarh. Asian J Plant Sci Res 2015;5(1):28-31.

46. Baskaran C, Rathabai V, Kanimozhi D. Screening for antimicrobial activity and phytochemical analysis of various leaf extract of Murraya koenigii. Int J Res Ayurveda Pharm 2011;2(6):1807-10.

47. Elshahat MR, Khadiga A, Abou T, Gehan FG, Nermin S. Antibacterial, antibiofilm and antitumor activities of grape and mulberry leaves ethnolic extracts towards bacterial clinical strains. Ann Agric Sci 2017;62(2):151-9.

48. Uma B, Prabhakar K, Rajendran S. Anticandidal activity of Asparagus racemosus. Indian J Pharm Sci 2009;71(3):342-3.

49. Maria CAL, Andre Parente de BB, Janiere Pereira de S, Felipe Queiroga SG, Edeltrudes de OL. Evaluation of antifungal activity and mechanism of action of citral against Candida albicans. Evid Based Complement Alternat Med 2014;2014:19.

50. Lima IO, De Medeiros Nobrega F, De Oliveira WA, De Oliveira LE, Albuquerque ME, Cunha FA, et al. Anti-candidal albicans effectiveness of citral and investigation of mode of action. Pharma Biol 2012;50(12):1536-41.

51. Lavanya J, Periyar S, Jeevitha PM, Preethi J, Aradana M. Antioxidant and antimicrobial activity of selected medicinal plants against human oral pathogens. Int J Pharm Pharm Sci 2016;8(9):71-8.

52. Anibal PC, Peixoto ITA, Foglio MA, Höfling JF. Antifungal activity of the ethanolic extracts of Punica granatum L. and evaluation of the morphological and structural modifications of its compounds upon the cells of Candida spp. Braz J Microbiol 2013;44(3):839-48. 